
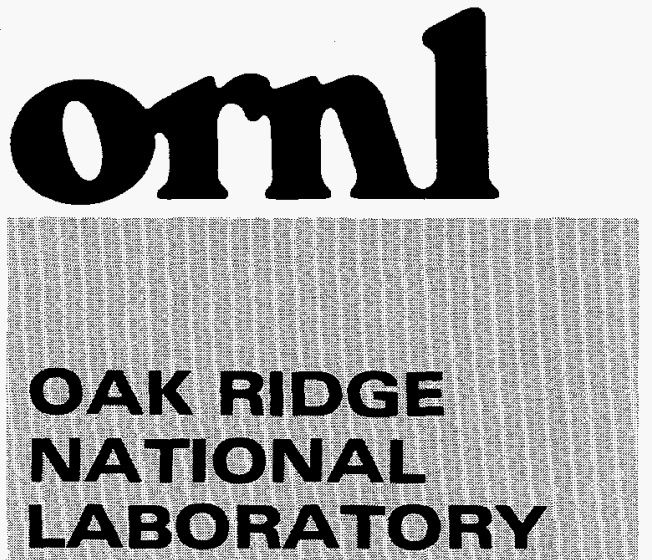

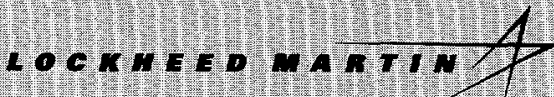

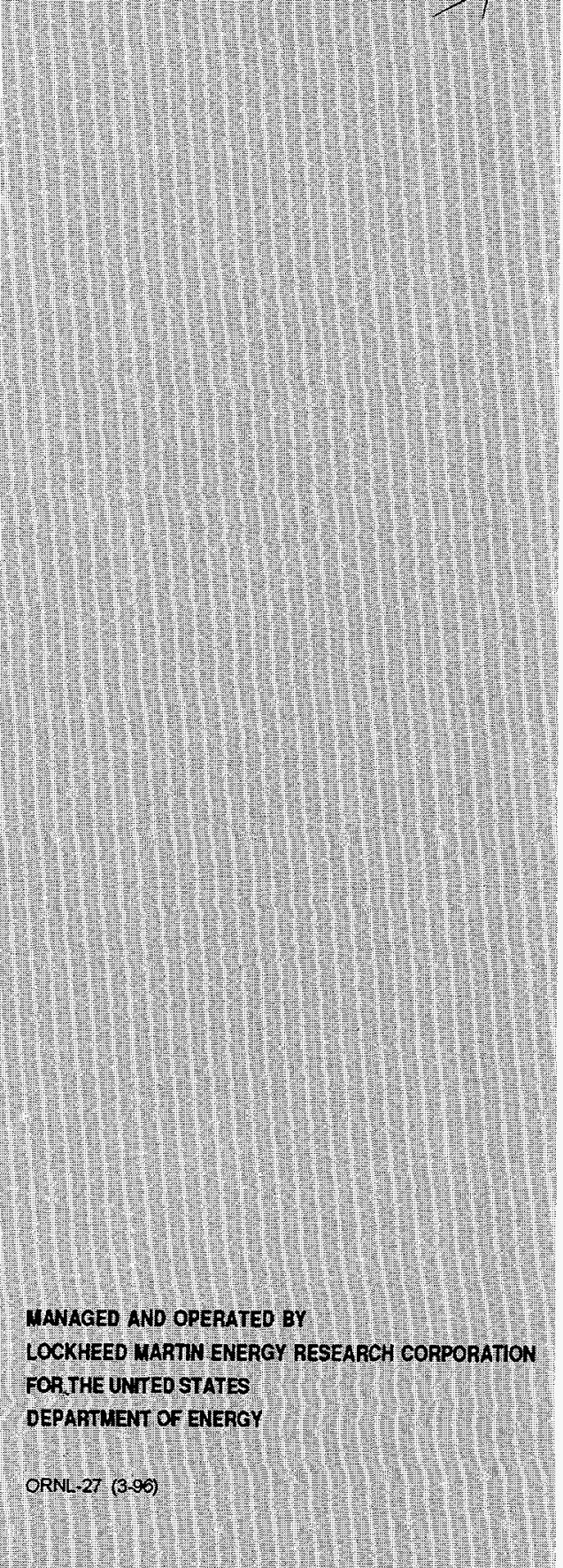

\section{RECEIVED \\ JUL 291998 \\ OSTI}

\title{
A Retrospective Study of The Chemical Analysis Cost for the Remediation of Lower East Fork Poplar Creek, Oak Ridge, Tennessee
}

Leon N. Klatt

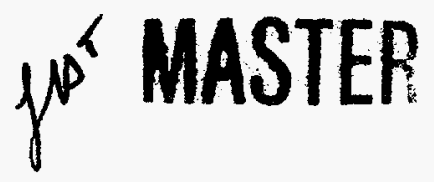

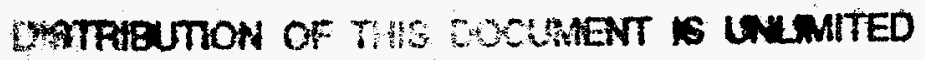


This report has been reproduced directly from the best available copy.

Available to DOE and DOE contractors from the Office of Scientific and Technical Information, P.O. Box 62, Oak Ridge, TN 37831; prices available from (615) 576-8401, FTS 626-8401.

Available to the public from the National Technical Information Service. U.S. Department of Commerce, 5285 Port Royal Rd., Springfield, VA 22161.

This report was prepared as an account of work sponsored by an agency of the United States Government. Neither the United States Government nor any agency thereof, nor any of their employess, makes any warranty, express or implied, or assumes any logal liability or responsibility for the accuracy, com pieteness, or usefuiness of any information, apparatus, product, or process disclosed, or represents tha! its use would not intringe privately owned rights. Reference herein to any specific commercial product, process, or service by trade name, trademark, manufacturer, or otherwise. does not necessarily constitute or imply its endorsement, recommendation, or favoring by the United States Government or any agency thereot. The views and opinions of authors expressed herein do not necessarily state or reflect those of the United States Government or any agency thereof. 


\section{DISCLAIMER}

Portions of this document may be illegible in electronic image products. Images are produced from the best available original document. 


\title{
A RETROSPECTIVE STUDY OF THE CHEMICAL ANALYSIS COST FOR THE REMEDIATION OF LOWER EAST FORK POPLAR CREEK, OAK RIDGE, TENNESSEE
}

\author{
Leon N. Klatt \\ Oak Ridge National Laboratory \\ P.O. Box 2008 \\ Oak Ridge, TN 37831-6285
}

Date Published: June 1998

Prepared for the

U.S. Department of Energy, Office of Science and Technology

Robotics Technology Development Program - Chemical Analysis Automation

\author{
Prepared by \\ OAK RIDGE NATIONAL LABORATORY \\ Oak Ridge, Tennessee 37831-6285 \\ Managed by \\ LOCKHEED MARTIN ENERGY RESEARCH CORP. \\ for the \\ U.S. DEPARTMENT OF ENERGY \\ Under contract DE-AC05-96OR22464
}




\section{CONTENTS}

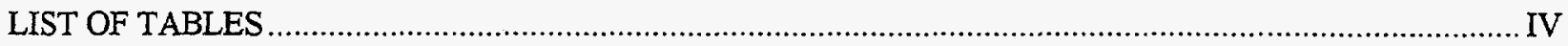

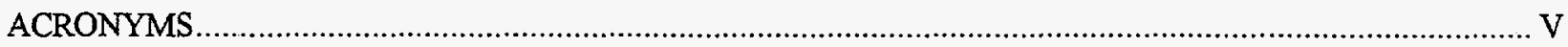

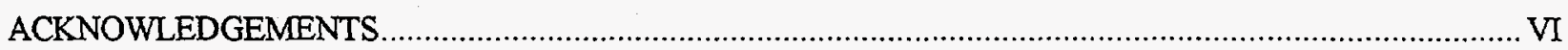

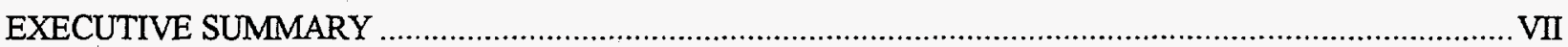

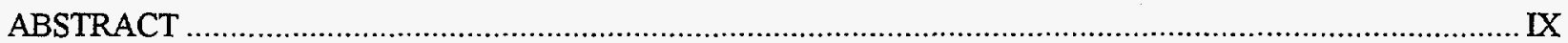

1. BACKGROUND INFORMATION ON LOWER EAST FORK POPLAR CREEK ….................................. 1

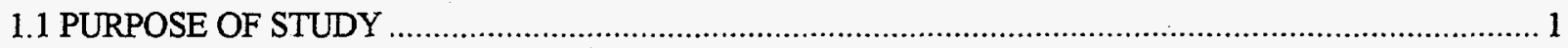

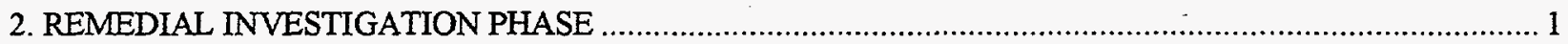

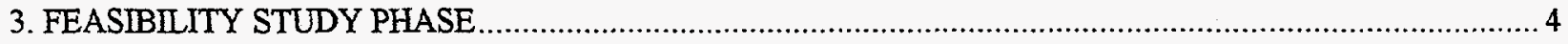

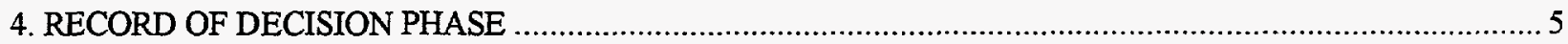

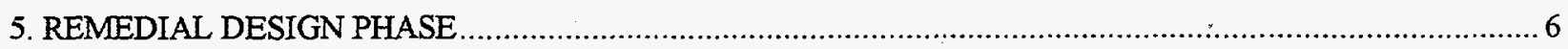

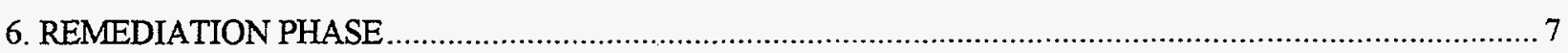

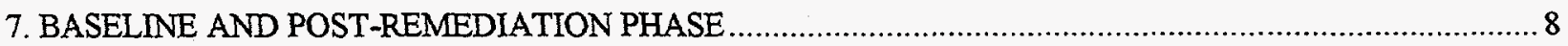

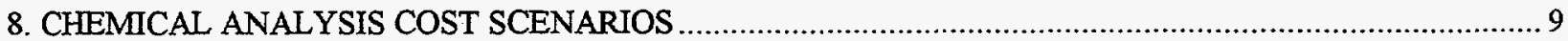

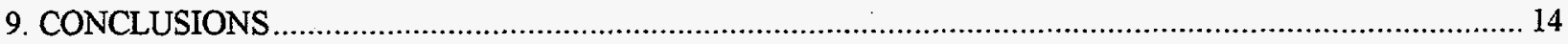




\section{LIST OF TABLES}

Table

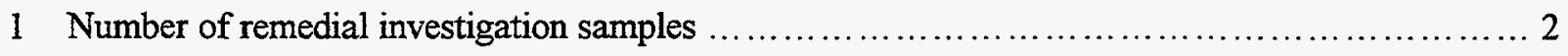

2 Volume of contaminated soil as a function of concentration ... ............................ 3

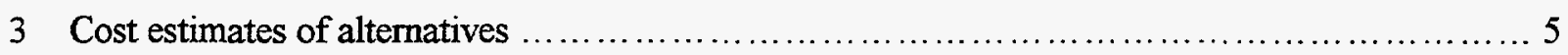

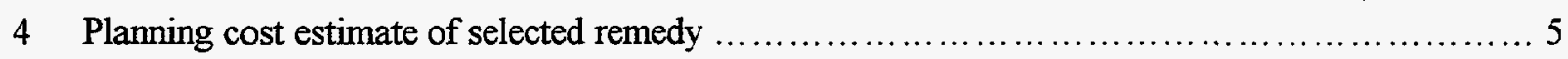

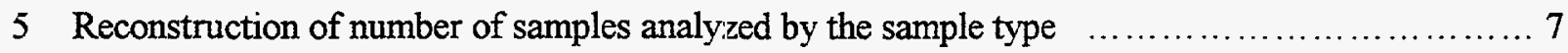

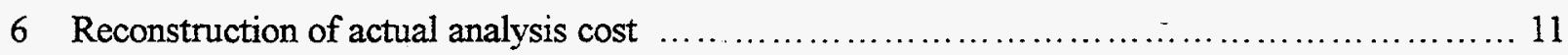

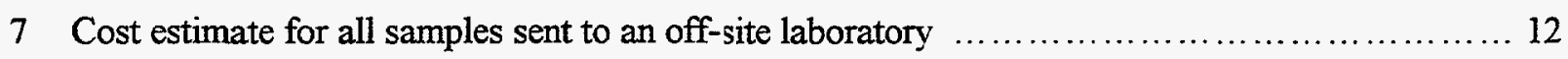

8 Cost estimate for maximum utilization of an on-site laboratory $\ldots \ldots \ldots \ldots \ldots \ldots \ldots \ldots \ldots \ldots \ldots$

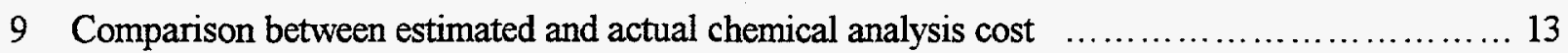




\section{ACRONYMS}

$\begin{array}{ll}\text { BRA } & \text { baseline risk assessment } \\ \text { CAA } & \text { Chemical Analysis Automation } \\ \text { CERCLA } & \text { Comprehensive Environmental Response, Compensation, and Liability Act } \\ \text { CLP } & \text { Contract Laboratory Program } \\ \text { COPC } & \text { contaminants of potential concern } \\ \text { DOE } & \text { U.S. Department of Energy } \\ \text { DQO } & \text { data quality objectives } \\ \text { ECU } & \text { excavation confirmation unit } \\ \text { EPA } & \text { U.S. Environmental Protection Agency } \\ \text { FS } & \text { Feasibility Study } \\ \text { LEFPC } & \text { Lower East Fork Poplar Creek } \\ \text { NAA } & \text { neutron activation analysis } \\ \text { NOAA } & \text { National Oceanic and Atmospheric Administration } \\ \text { PAH } & \text { polycyclic aromatic hydrocarbon } \\ \text { PCB } & \text { polychlorinated biphenyl } \\ \text { PCU } & \text { perimeter confirmation unit } \\ \text { QA } & \text { quality assurance } \\ \text { QC } & \text { quality control } \\ \text { RGO } & \text { remediation goal option } \\ \text { ROD } & \text { Record of Decision } \\ \text { SWA } & \text { site wide alternatives }\end{array}$




\section{ACKNOWLEDGEMENTS}

This research was sponsored by the Office of Science and Technology, U.S. Department of Energy, under contract DE-AC05-960R22646 with Lockheed Martin Energy Research Corporation.

The author thanks John Lea, Jacobs Engineering, for helpful discussion related to the Lower East Fork Poplar Creek remediation and for his careful review of this report. 


\section{EXECUTIVE SUMMARY}

A retrospective study of the remediation of Lower East Fork Poplar Creek (LEFPC) in Oak Ridge, Tennessee was completed. The purpose of the study was to determine the cost of the chemical analysis required by the LEFPC remediation project, to ascertain the steps the project took to provide the required chemical analysis services, and how other project costs were impacted as a result of how the chemical analysis services were provided.

The study was conducted by reviewing the public Comprehensive Environmental Response, Compensation, and Liability Act (CERCLA) record documents associated with the remediation of LEFPC and through discussions with the project staff involved or familiar with the project.

LEFPC originates in the Y-12 Plant and flows through the city of Oak Ridge for about 14.5 miles until it joins Poplar Creek just north of the East Tennessee Technology Park (formerly the K-25 Site). The watershed of LEFPC is approximately $30 \mathrm{mile}^{2}$ and includes portions of the DOE-Oak Ridge Reservation, and commercial, residential, and agricultural use areas.

The creek and its floodplain were contaminated by releases from the Y-12 Plant. Mercury was the primary contaminant of concern. It has been estimated that between 239,000 and $470,000 \mathrm{lbs}$ of mercury were released into the creek. Although other heavy metals and some organic compounds were found during the remedial investigation, these were present in much smaller quantities. The contamination was located in the 100-year floodplain, which encompasses approximately 670 acres.

The remediation took place in two phases. The first phase involved the excavation of about $5,560 \mathrm{yd}^{3}$ of soil at the National Oceanic and Atmospheric Administration (NOAA) site about 1 mile north of the Y-12 Plant in 1996. The second phase involved the excavation of $39,200 \mathrm{yd}^{3}$ at another NOAA site and at the Bruner site, located about 6 miles downstream from the NOAA site, in 1997. The total area remediated was about 19 acres.

The cleanup cost for LEFPC was $\$ 7.1$ million. The total cost of the LEFPC project was $\$ 25.7$ million; about $\$ 18.6$ million was spent meeting the requirements of the CERCLA process. The entire project took 7 years.

The project obtained special regulatory approval to use two methods for the determination of mercury in soils that are not part of the U.S. Environmental Protection Agency SW-846 methods manual.

For the entire project (remedial investigation through cleanup) a total of 7708 samples ( 1 sample for each $5.8 \mathrm{yd}^{3}$ of soil remediated) were analyzed for mercury. The mercury analysis cost was $\$ 678,000$, which represents $2.6 \%$ of the total project cost and $9.6 \%$ of the cleanup cost.

During the cleanup phase of the project, an on-site laboratory was used. The estimated cost savings that the on-site laboratory provided fall into two categories:

- direct reduction of costs associated with chemical analysis and sample shipment totaling approximately $\$ 38,000$, which represents a $5.3 \%$ savings relative to the estimated cost of using an off-site laboratory, and 
- savings in the amount of $\$ 890,000$ (12.5\% of the $\$ 7.1 \mathrm{M}$ cleanup cost), associated with expediting execution of the cleanup work by providing rapid $(<3$ hours $)$ sample result turnaround time.

Given the current state of the art of field-deployable chemical laboratories and the regulatory acceptance of field screening methods, LEFPC project management could not have achieved any additional cost savings for chemical analysis.

The study indicates that the availability of automated chemical analysis systems that meet regulatory requirements and that can be deployed in the field (e.g., Chemical Analysis Automation type technology) could have provided an additional savings of $\$ 443,000$ (the difference between the actual cost and the projected cost for deployment of an on-site laboratory during the remedial investigation and cleanup phases). The study also indicates that the total savings that automated field-deployable analysis systems would have provided, compared with the conventional approach of sending all samples to an off-site laboratory, was about $\$ 1.3$ million (the sum of estimated savings provided by full field deployment of automated analysis systems, $\$ 443,000$, and by expediting the cleanup, $\$ 890,000$ ); a savings of $18 \%$ of the cleanup cost.

The manner in which the analytical chemistry services were procured by the LEFPC project suggests several important development considerations for the U.S. Department of Energy's Chemical Analysis Automation project. First, because the largest cost saving is associated with expediting the actual cleanup work, the automated chemical analysis systems must be site deployable and must provide rapid sample result analysis turnaround times commensurate with the specific cleanup work activities; generally, this would be less than 24 hours. Second, the performance of the automated analysis systems must meet the relevant state and federal regulatory requirements. Third, the automation system must be flexible and adaptable to facilitate the introduction of new chernical analysis methodology. Fourth, the automation technology must be robust and reliable. Finally, the automated systems must be implemented in a manner acceptable to the environmental remdiation business. The results from a recent technology demonstration (Development Testing of the Chemical Analysis Automation Polychlorinated Biphenyl Standard Analysis Mehtod During the Surface Soil Sampling at the David Witherspoon 1630 Site, " ORNL/TM-13590, February 1998) show that the CAA project is addressing each of the items. 


\begin{abstract}
A retrospective study of the remediation of Lower East Fork Poplar Creek (LEFPC) in Oak Ridge, Tennessee was completed. The study was conducted by reviewing the public Comprehensive Environmental Response, Compensation, and Liability Act record documents associated with the remediation of LEFPC and through discussions with the project staff involved or familiar with the project. The remediation took place in two phases. The first phase involved the excavation of about $5560 \mathrm{yd}^{3}$ of soil at the National Oceanic and Atmospheric Administration (NOAA) locations in 1996. The second phase involved the excavation of $39,200 \mathrm{yd}^{3}$ at another NOAA location and at the Bruner location in 1997. The cleanup cost for LEFPC was \$7.1 million. For the entire project (remedial investigation through cleanup), a total of 7708 samples ( 1 sample for each $5.8 \mathrm{yd}^{3}$ of soil remediated) were analyzed for mercury. The project obtained special regulatory approval to use two methods for the determination of mercury in soils that are not part of the Resource Conservation and Recovery Act SW-846 methods manual. The mercury analysis cost was $\$ 678,000$, which represents $9.6 \%$ of the cleanup cost. During the cleanup phase of the project, an on-site laboratory was used. The estimated cost savings that the on-site laboratory provided fall into two categories:
\end{abstract}

- direct reduction of costs associated with chemical analysis and sample shipment totaling approximately $\$ 38,000$, which represents a $5.3 \%$ savings relative to the estimated cost of using an off-site laboratory, and

- savings in the amount of $\$ 890,000$ ( $12.5 \%$ of the $\$ 7.1 \mathrm{M}$ cleanup cost), associated with expediting execution of the cleanup work by providing rapid ( $<3$ hours) sample result turnaround time.

Given the current state of the art of field-deployable chemical laboratories and the regulatory acceptance of field screening methods, LEFPC project management could not have achieved any additional cost savings for chemical analysis.

The manner is which the analytical services were procured for the LEFPC project suggest that the development of new chemical analysis technology must address deployment, performance, regulatory, robustness, reliability, and business appropriateness factors if the technology is to be used in environmental remediation. 


\section{BACKGROUND INFORMATION ON LOWER EAST FORK POPLAR CREEK}

Lower East Fork Poplar Creek (LEFPC) originates in the Oak Ridge Y-12 Plant and flows through the city of Oak Ridge for about 14.5 miles until it joins Poplar Creek just north of the East Tennessee Technology Park (formerly the K-25 Site). Stream depth ranges from 3 to $9 \mathrm{ft}$. The average flow of LEFPC over the 25 -year period of record is $51.4 \mathrm{ft}^{3} / \mathrm{sec}$. The watershed of LEFPC is approximately $30 \mathrm{mile}^{2}$ and includes portions of the U. S. Department of Energy's (DOE) Oak Ridge Reservation and commercial, residential, and agricultural use areas.

The creek and its floodplain have been contaminated by releases from the $Y-12$ Plant. Mercury was the primary contaminant of concern. It has been estimated that between 239,000 and $470,000 \mathrm{lbs}$ of mercury were released into the creek. Releases from plant operations stopped in 1963, but mercury continues to be released into the creek from secondary contaminated sources, such as building drain systems and sewers. The current release averages approximately 20 gram per day. Although other heavy metals and some organic compounds were found during the remedial investigation, these were present in much smaller quantities. The contamination was located in the 100 year floodplain, which encompasses approximately 670 acres. The remediation of LEFPC was completed under the requirements defined by the Comprehensive Environmental Response, Compensation, and Liability Act (CERCLA).

\subsection{PURPOSE OF STUDY}

The purpose of the retrospective study was to determine the cost of the chemical analysis services required by the project, ascertain the steps the project took to provide the required chemical analysis services, and how other project costs were impacted as a result of how the chemical analysis services were provided. From the analysis of the data, projections are made related to the potential additional cost savings that could have been provided by field-deployable automated chemical analysis systems that meet all regulatory requirements.

The study was conducted by reviewing the public record documents associated with the remediation of LEFPC and through discussions with the project staff involved or familiar with the project.

\section{REMEDIAL INVESTIGATION PHASE}

The remedial investigation ${ }^{1}$ was conducted in three phases. Field sampling, laboratory analysis, and data evaluation began in autumn of 1990 and continued through the summer of 1992; a field study of wetlands occurred in September and October 1993. All of the laboratory work and the reporting of laboratory data were performed under the U.S. Environmental Protection Agency (EPA) Contract Laboratory Program (CLP) or approved equivalent.

\footnotetext{
${ }^{1}$ East Fork Poplar Creek - Sewer Line Beltway Remedial Investigation Report, DOE/OR/02-1119\&D2, January 1994.

${ }^{2}$ Addendum to the East Fork Poplar Creek-Sewer Line Beltway Remedial Investigation Report, DOE/OR/021119\&D2\&A1/R1, June 1994.
} 
Phase Ia was designed to determine the nature of the contamination and to identify the contaminants of potential concern. More than 500 surface water, creek sediment, and surface and subsurface soil samples were taken along the watershed and at a noncontaminated reference site. These samples were analyzed for 182 inorganic, organic, and radionuclide analytes, as well as geotechnical parameters and soil chemistry related to treatability studies. As a result of the Phase Ia studies, 12 groundwater monitoring wells were installed. A total of 22 monitoring wells were sampled quarterly to characterize the groundwater quality and hydrogeology of the floodplain.

Phase Ib expanded the soil and sediment sampling. Begun in the summer of 1991 , Phase $\mathrm{Ib}$ was designed to establish the extent and level of contaminants of potential concern (COPC). The Phase $\mathrm{Ib}$ sampling plan involved the identification of transects across the floodplain at 100-m intervals along the entire length of the creek; a total of 159 transects were required. Soil samples were taken along each transect at $20-\mathrm{m}$ spacings from the creek bank to the elevation of the 100 year floodplain. Stream sediment samples were taken at odd-number transects. Subsurface soil samples were taken to a depth of $4 \mathrm{ft}$. More than 3400 samples were taken during Phase $\mathrm{Ib}$. The number of samples taken during Phase $\mathrm{Ia}$ and $\mathrm{Ib}$ is summarized in Table $\mathrm{I}$.

Table 1. Number of remedial investigation samples

\begin{tabular}{|c|c|c|c|}
\hline \multirow[b]{2}{*}{ Sample type } & \multicolumn{3}{|c|}{ Number of samples } \\
\hline & Phase Ia & Phase $\mathrm{Ib}$ & Total \\
\hline Field & 569 & 3445 & 4014 \\
\hline Quality control & 304 & 405 & 709 \\
\hline Total & 873 & 3850 & 4723 \\
\hline
\end{tabular}

Phase $\mathrm{Ib}$ relied upon neutron activation analysis (NAA), a non-CLP method. Data quality objectives for NAA were established to meet the precision and accuracy of CLP methods, except for the method detection limit. The NAA method detection limit for the LE]:PC floodplain soils was $11 \mathrm{ppm}$. EPA granted special approval for the use of NAA in this remedial investigation.

The data from the remedial investigation showed a. large number of COPCs in all LEFPC media. The COPCs included 13 heavy metals, 9 polycyclic aromatic hydrocarbons (PAHs), 2 polychlorinated biphenyls (PCBs), and 11 radionuclides. For the heavy metals, mercury was by far the most significant contributor, with $>85 \%$ of the total toxicity. For the radionuclides, total uranium accounted for $98 \%$ of the total activity. The COPCs in the soil and sediments were identical. The COPCs for groundwater were similar, except that silver was not detected, and PAHs and PCBs were not significant. Surface water under baseline flow conditions had no COPCs; all the metals and organics detected were below the Safe Drinking Water Act maximum contaminant levels and met the federal water quality criteria for the protection of freshwater organisms.

Studies related to mercury speciation and a special field investigation related to wetlands were conducted and reported as an addendum to the remedial investigation report. 
During the wetland investigation, samples were taken from trees (core samples), soils, vegetation, animals (crayfish, frogs, toads, shrews and salamanders), fish (stonerollers and stripped shiners), and periphyton (the primary food source of stonerollers). These samples were analyzed for total mercury and PCBs. A total of 250 samples were collected as part of the wetland investigation.

Considerable effort was spent determining the predominate forms of mercury in the soil. Because the solubility, mobility, toxicity, and biological uptake of mercury are highly dependent on its form, or species, this effort was critical to the human and ecological health assessment activity. For example, methylmercury is highly toxic and readily absorbed by organisms, while mercury sulfide is relatively nontoxic and has minimal biological uptake. The result of this effort was the determination that mercury sulfide and metallic mercury are the predominate forms of mercury in LEFPC soils. Approximately $85 \%$ of the mercury is present as mercury sulfide. Direct analysis for methylmercury showed that it was present at less than $8 \mathrm{ppb}$.

A geostatistical method was used to estimate the volumes of soils contaminated at the 50 - and 200-ppm levels as a function of soil depth. The results are summarized in Table 2.

Table 2. Volume of contaminated soil as a function of concentration

\begin{tabular}{ccc}
\hline Soil depth & \multicolumn{2}{c}{ Soil volume in units of $1000 \mathrm{yd}^{3}$} \\
\cline { 2 - 3 } $0-16$ inches & 162 & $\geq 200 \mathrm{ppm}$ mercury \\
\hline $16-32$ inches & 35 & 31 \\
Total & 197 & 13 \\
\hline
\end{tabular}

Risk assessment is an essential element of a remedial investigation. A baseline risk assessment (BRA) is conducted to assess site conditions in the absence of remedial actions. The primary objectives of the BRA are to determine whether there is an "imminent and substantial" endangerment to human health and ecological receptors based on current and future exposure potential. The determination of the need for site remediation and a remediation goal option are the outcomes of the BRA process.

The BRA studies showed that the contaminant levels in the floodplain shallow groundwater exceeded the EPA target risk values throughout the floodplain. The floodplain soils posed a risk of adverse health effects that exceeded the EPA target risk values at six locations. The risk was primarily due to mercury, and the exposure pathway was ingestion. Since no one was using the groundwater from the floodplain as a source of drinking water, or is likely to do so in the future because all residents are provided with city water, ingestion of LEFPC groundwater was not considered a substantial risk to human health. However, the inadvertent ingestion of floodplain soils, particularly by children, was considered a substantial health risk. The remediation goal option identified for mercury in the floodplain soil was $200 \mathrm{ppm}$. 


\section{FEASIBILITY STUDY PHASE}

The EPA requires that remedial action be protective of human health and the environment by eliminating, reducing, and/or controlling the risks identified during the remedial investigation. Potential general actions include no action, institutional actions, containment, removal, treatment, disposal, and beneficial use. Seven site-wide alternatives (SWA) for LEFPC were idertified during the feasibility study phase. ${ }^{3}$

- SWA 1. This is the No Action alternative. This alternative provided the baseline for comparing the other alternatives. Under this alternative, environmental monitoring along with a 5-year periodic review was proposed.

- SWA 2. This alternative involved exctvation of soil contaminated with $>180 \mathrm{ppm}$ mercury from the residential use areas and disposal of the soil in an approved landfill. For the other use areas, containment and institutional actions were proposed. Installation of an 18-in. soil cover where soil contamination is $>200 \mathrm{ppm}$, and restrictions on the use of the nonresidential areas were proposed.

- SWA 3. This alternative involved excalvation of soil contaminated with $>180 \mathrm{ppm}$ mercury from the residential use area and the excavation of soil contaminated with $>200 \mathrm{ppm}$ from the other use areas. The contaminated soil would be disposed of in an approved landfill.

- SWA 4. This alternative involved excavation and treatment of soil contaminated with $>180 \mathrm{ppm}$ mercury from the residential use area. A treatment process involving lowtemperature thermal desorption was proposed. The cleaned soil would be used as backfill in the excavated areas. Residuals from the treatment process would be temporarily stored for transport to an approved off-site disposal facility. A containment and institution controls action, similar to that identified in SWA 2, was proposed for the other use areas.

- SWA 5. This alternative involved excavation and treatment of soil contaminated with $>180 \mathrm{ppm}$ mercury from the residential use area and of soil contaminated with $>200 \mathrm{ppm}$ mercury from the other use areas. A treatment process involving low-temperature thermal desorption was proposed. The treated soil would be used as backfill in the excavated areas. Residuals from the treatment process would be temporarily stored for transport to an approved off-site disposal facility.

- SWA 6. This alternative involved containment and institutional actions on all use areas. DOE would acquire the real estate interest for all areas containing $>180 \mathrm{ppm}$ mercury, and access control fencing would be installed around the acquired areas.

- SWA 7. This alternative involved the excavation of soil contaminated with $>180 \mathrm{ppm}$ from the residential use area and disposal of: the soil in an approved landfill. Institutional actions, such as land use reclassification, future land use restrictions, construction permit restrictions, and signs, would be applied to the other use areas.

\footnotetext{
${ }^{3}$ Feasibility Study for the Lower East Fork Poplar Creek - Sewer Line Beltway, DOE/OR/02-1185\&D2, Vol. 1 and 2, August 1994.
} 
Cost estimates for each of these alternatives are summarized in Table 3.

Table 3. Cost estimates of alternatives

\begin{tabular}{cc}
\hline Site-wide alternative & Cost (in \$M 1993 dollars) \\
\hline 1 & 12 \\
2 & 48 \\
3 & 52 \\
4 & 59 \\
5 & 70 \\
6 & 41 \\
7 & 31 \\
\hline
\end{tabular}

\section{RECORD OF DECISION PHASE}

The Remedial Investigation Report concluded that a remediation goal of $180 \mathrm{ppm}$ mercury was required to protect human health. During the record of decision ${ }^{4,5}$ (ROD) process, SWA 3 was selected as the remedy that addresses the human health and ecological threats. During the ROD process, the remediation goal option (RGO) was changed from $180 \mathrm{ppm}$ mercury to $400 \mathrm{ppm}$ mercury for the protection of human health, and the ecological RGO was set at $200 \mathrm{ppm}$ mercury (rounded up from $180 \mathrm{ppm}$ mercury). A risk management decision was made during the ROD process not to remediate soil containing $<400 \mathrm{ppm}$ mercury, as doing so would destroy more habitat have been than would have benefitted from remediating to $200 \mathrm{ppm}$ mercury. A 5-year ecological monitoring plan was implemented to ensure that the ecosystem was not adversely affected by an RGO of $400 \mathrm{ppm}$ mercury. Input from the public during the comment period resulted in a change in the bioavailability factor from $30 \%$ to $10 \%$, which translated into the higher remediation goal. The change in the bioavailability factor was based upon the fact that the BRA used data for mercury chloride, a much more soluble and reactive form of mercury, instead of mercury sulfide because the only information available was for mercury chloride. This change in remediation goal decreased the estimated amount of soil to be excavated, reduced the number of areas needing remediation from six to two, and lowered the estimated remediation cost by $\$ 30$ million. Table 4 summarizes the planning cost estimate of the selected remedy.

Table 4. Planning cost estimate of selected remedy

\begin{tabular}{cc}
\hline Cost component & Cost (SM) \\
\hline Design & 1.4 \\
Cleanup & 12.1 \\
Operating and maintenance & 3.8 \\
Indirect an overhead & 5.0 \\
Contingency & 3.6 \\
Total & 25.9 \\
\hline
\end{tabular}

\footnotetext{
${ }^{4}$ Proposed Plan, East Fork Poplar Creek - Sewer Line Beltway, Oak Ridge, Tennessee, DOE/OR/02-1209\&D3, January 1995.

${ }^{5}$ Record of Decision for Lower East Fork Poplar Creek, Oak Ridge, Tennessee, DOE/OR/02-1370\&D2, July 1995.
} 
The cost of the chemical analyses required to support the actual remediation was lumped into the cleanup category. The operating and maintenance category includes the cost of operating and maintaining the landfill leachate storage system and the post-remediation monitoring of the floodplain for 5 years.

The ROD process resulted in the development of a confirmatory sampling plan as well as an additional preremediation sampling effort to more fully delineate the $400 \mathrm{ppm}$ contamination boundaries. John Lea stated that approximately 400 soil samples were collected to define the $400 \mathrm{ppm}$ contamination contours. ${ }^{6}$ The ROD process also added the requirements that the excavated areas be backfilled with clean soil to restore the original land contours, the excavated areas be revegetated, , and a post-remediation monitoring program be instituted to insure the effectiveness of the remediation.

The section of the ROD report dealing with implernentability it is states that the low-temperature thermal desorption process (SWAs 4 and 5 identified in the Feasibility Study Report) was judged to be the hardest part of the plan to implement because "the full scale effectiveness and implementability have not been proven." However, the report states "that low-temperature desorption is an EPA-accepted, best demonstrated available technology, effective in removing mercury from LEFPC'soils in bench-scale and pilot tests."

\section{REMEDIAL DESIGN PHASE}

The remedial design ${ }^{7}$ was based upon the project's ROD report, which selected SWA 3 of the feasibility study. The remediation design plan stated that the remediation would be done in two phases. The first phase involved the excavation of soil at the National Oceanic and Atmospheric Administration (NOAA) site located about one mile north of the Y-12 Plant in 1996. The second phase involved the excavation of soils at the NOAA site and the Bruner site, located abut 6 miles downstream from the NOAA site, in 1997. The assumptions for the remedial design included

- areas in the 100 year floodplain with $>400$ ppm mercury content will be remediated;

- the contaminated soil will be excavated and disposed of it in an approved landfill, the excavated areas will be backfilled to restore the original land contours, and the excavated areas will be revegetated;

- the average depth of soil to be excavated is approximately 16 in. (the contamination at some areas at the Bruner location extended to a depth of $32 \mathrm{in.)}$;

- the total volume of soil to be excavated is approximately $27,000 \mathrm{yd}^{3}$;

- decontamination water, waste water from soil dewatering, rainwater inflow, and groundwater infiltration into open excavated areas will be treated prior to discharge to the city of Oak Ridge water treatment plant;

\footnotetext{
${ }^{6}$ Notes taken by L. N. Klatt during a meeting with John Lea, Jacobs Engineering, March 23, 1998. (John Lea was the project leader for the LEFPC remediation project.)

${ }^{7}$ Remedial Design Work Plan for the Lower East Fork: Poplar Creek Operable Unit, Oak Ridge, Tennessee, DOE/OR/01-1395\&D2, February 1996.
} 
- sediment, surface water, soil, and organisms will be monitored for five years after the remediation is completed; and

- about 1.5 acres of the contaminated area is classified as wetlands.

\section{REMEDIATION PHASE}

A confirmatory sampling and analysis plan ${ }^{8}$ for LEFPC was developed and implemented during the remediation. The areas to be excavated were divided into excavation confirmation units (ECUs) of $2500 \mathrm{ft}^{2}$. A perimeter confirmation unit (PCU) was defined at the borders of the excavated areas; the PCU extended outward $10 \mathrm{ft}$ from the ECUs. To determine the number of samples to be taken in each ECU, 74 randomly selected samples were taken from areas outside the PCU to obtain estimates of the statistical parameters for the sampling model. Using the remedial action design goal that all contamination would be removed at the $95 \%$ confidence level, the results of the confirmatory sampling design yielded four samples per ECU.

Sample points within each ECU were determined by a random process. Intersecting grid lines were placed at intervals of $5 \mathrm{ft}$ on each ECU, and a random number method was used to select the sample grid points. The location of each sample was recorded in the project database.

Screening core samples were taken over a depth of 2 to 8 in. and analyzed by the on-site laboratory. These samples were used only to guide the excavation. The confirmatory sample was a 16-in.-deep core that was dried, composited over the core depth, split, and analyzed. The confirmatory samples were analyzed by the on-site laboratory. Based upon the quality assurance (QA) plan for the confirmatory sampling and analysis activities, the total number of samples generated by the remediation was 1438 . The total number of soil samples analyzed during the remediation was more than $3000^{6}$, which includes approximately 1800 samples required to meet the landfill waste acceptance criterion. The breakdown by sample type is summarized in Table 5.

Table 5. Reconstruction of number of samples analyzed by the sample type

\begin{tabular}{lc}
\hline \multicolumn{1}{c}{ Sample type } & Number of samples \\
\hline Statistical design samples & 74 \\
ECU and PCU & 1021 \\
Field duplicates & 112 \\
Equipment rinsate & 111 \\
Off-site lab quality assurance & 40 \\
Off-site laboratory & 80 \\
Waste acceptance samples & 1800 \\
\hline
\end{tabular}

Because excavation and work areas were within the 100 year floodplain of LEFPC, soil erosion and sediment control measures and a hazardous waste management program had to be implemented. A water treatment unit was placed on the site to decontaminate the water before discharge.

${ }^{8}$ Confirmatory Sampling and Analysis Plan for the Lower East Fork Poplar Creek Operable Unit, Oak Ridge, Tennessee, Y/ER-258, April 1996. 
Remediation of LEFPC was completed in September 1997. The total volume of soil remediated was 44,760 $\mathrm{yd}^{3}$, which was $66 \%$ more than the estimated amount used in the remedial design. The total area remediated was about 19 acres.

The remediation cost of LEFPC was $\$ 7.1$ million. approximately $59 \%$ of the cleanup estimate shown in Table 4. The total cost of the LEFPC project was approximately $\$ 25.7$ million. About $\$ 18.6$ million was spent meeting the requirements of the CERCLA process; this cost is not included in the data shown in Table 4. The entire process took 7 years.

\section{BASELINE AND POST-REMEDIATION PHASE}

The post-remediation ${ }^{9}$ monitoring will not be done to monitor human health; rather, it will be done to assess the impact upon the ecological receptors. Ten measurement endpoints were identified for the postremediation monitoring:

- the total mercury and methylmercury in earthworms taken from the LEFPC floodplain;

- total mercury and methylmercury in starling nestlings obtaining their primary diet from the LEFPC floodplain;

- the fertility and viability of starlings;

- total mercury and methylmercury in fish that are eaten by predators;

- toxicity of LEFPC sediment to sediment-dwelling organisms relative to a reference site and to a laboratory control;

- toxicity of LEFPC surface water to aquatic biota relative to a reference site;

- total mercury and methylmercury in surface water;

- the abundance, frequency, and distribution of wetland species in the restored wetland areas;

- duration of soil saturation or inundation during the growing season; and

- if the earthworm population declines, then the toxicity of the floodplain will be evaluated.

Based upon the frequency of the sampling activities and the number of locations, this measurement endpoint plan will result in the submission of about 400 samples annually for total mercury and methylmercury determinations.

The presence of any groundwater wells in the LEFPC floodplain will be reported to the Department of Energy and mitigating actions taken, if necessary.

\footnotetext{
${ }^{9}$ Baseline and Post-Remediation Monitoring Program Plan for the Lower East Fork Poplar Creek Operable Unit, Oak Ridge, Tennessee, Y/ER-262, April 1996.
} 


\section{CHEMICAL ANALYSIS COST SCENARIOS}

This section summarizes three cost scenarios. The first scenario attempts to reconstruct the actual chemical analysis costs. The second constructs an alternative involving the use of an off-site laboratory for all the chemical analyses. The third constructs an alternative involving the maximum use of an on-site laboratory for all the chemical analyses. This approach was taken because a key premise related to the deployment of the Chemical Analysis Automation ${ }^{10,11,12}$ (CAA) technology is its co-location at a remediation site to provide rapid turnaround of results and to avoid costs associated with the shipment of samples to an offsite laboratory. In all cases, it is assumed that $10 \%$ of the samples would be split and sent to a second independent laboratory to provide a QA check of the on-site laboratory. The use of an independent laboratory ensures that the data quality objectives defined for each phase of the CERCLA process have been met and are defensible.

It is important to note that the LEFPC project took steps to reduce the cost of chemical analysis. The project used an on-site laboratory during the actual remediation. The LEFPC project also developed and acquired EPA approval for the use of a chemical method ${ }^{13}$ that was less costly than the method specified in the EPA SW-846 manual. ${ }^{14}$ In the cost scenarios, a value was not included for the development of the new method or for the cost of acquiring the approval for its use.

Because mercury was the contaminant of concern in LEFPC, the scenarios only address the mercury analysis cost. Other chemical analysis cost items that are not included in the scenarios are the costs associated with Phase Ia remedial investigation, the daily sampling of surface waters, the quarterly sampling of groundwater monitoring wells, and the environmental and biological monitoring during the entire remediation period. The costs associated with the latter three activities were estimated to be $\$ 250,000, \$ 88,000$, and $\$ 335,000$, respectively. The cost of intralaboratory QA and quality control samples is not included because this cost is normally embedded in the cost charged the client for each sample received by the laboratory. An estimate of potential cost savings during the post-remediation phase is not included.

The cost per sample and sample turnaround time information were obtained from discussions with John Lea, Jacobs Engineering. ${ }^{6}$ No attempt has been made to review the actual project cost data. The cost figures used in the scenarios are

- $\$ 125$ per sample for the off-site NAA method for the determination of total mercury,

\footnotetext{
${ }^{10}$ M. Monagle, F. Settle, and L. N. Klatt, "An Overview of The Contaminant Analysis Automation Program," LALP 95-110, April 1995.

${ }^{11}$ Settle, F. A. Jr.; Hollen, R.; Yarbrough, L. W.; "The Contaminant Analysis Automation Project," Amer. Lab. April 1995.

${ }^{12}$ Hunt, M. A.; Klatt, L. N.; Thompson, D. H.; Trent, D. J.; Younkin', J. R.; Dale, D. E.; Hakonson ,K.; Rzescutko, C.; "Development Testing of The Chemical Analysis Automation Polychlorinated Biphenyl Standard Analysis Method During Surface Soil Sampling at the David Witherspoon 1630 Site," ORNL/TM-13590, February 1998.

${ }^{13}$ Confirmatory Sampling and Analysis Plan for the Lower East Fork Poplar Creek Operable Unit, Oak Ridge, Tennessee, Appendix "Static Headspace Analysis for Mercury in Soils," Y/ER-258, April 1996.

14 "Mercury in Solid Waste or Semisolid Waste (Manual Cold-Vapor Technique)," Method 7471A, SW-846, Update III, June 1997.
} 
- $\$ 30$ per sample for the on-site total mercury determinations using the static head space method,

- $\$ 30$ per sample for the on-site total mercury determinations using the static head space method yielding a CLP data package,

- $\$ 50$ per sample for the off-site total mercury determinations using the static head space method to provide the QA check of the on-site laboratory CLP results,

- $\$ 50$ per sample for a second off-site laboratory to perform the laboratory QA check data,

- $\$ 50$ per sample for an off-site laboratory to perform the total mercury analysis for waste acceptance, and

- $\$ 3$ per sample for shipping samples to the off-site laboratory.

The sample turnaround times specified and achieved during the execution of the remediation were

- on-site laboratory field screening results, $<3$ hours;

- on-site laboratory CLP data package, 24 hours;

- off-site laboratory performing the confirmatory QA check, 24 hours; and

- off-site laboratory performing the laboratory QA check, 7 days.

Tables 6,7 , and 8 reconstruct the costs for the first, second, and third scenarios, respectively.

The results in Tables $6-8$ suggest several conclusions. First, the chemical analysis cost represented about $9.6 \%$ of the $\$ 7.1 \mathrm{M}$ cleanup cost. Second, the use of the on-site laboratory during the actual remediation saved about $\$ 38,000$ (the difference between the total costs shown in Tables 6 and 7), which represents a $5.3 \%$ savings relative to the estimated cost of using an off-site laboratory (Table 7), in direct chemical analysis cost. The use of an on-site laboratory during both the remedial investigation and cleanup phase could have saved as much as $\$ 443,000$ (the difference between the total costs shown in Tables 6 and 8) or $65 \%$ of the actual analytical cost (estimated savings of $\$ 443,000$ relative to the actual cost of $\$ 678,000$ ). Other cost savings provided by the on-site laboratory are discussed in the following pages.

It is interesting to compare three of the actual cost items in Table 6 with estimates contained in the Feasibility Study and ROD reports These results are summarized in Table 9. The difference between estimated and actual cost is $\$ 3,302,000$, which is $66 \%$ of the difference between the estimated cleanup cost ( $\$ 12.1$ million, listed in Table 4) and the actual cleanup cost ( $\$ 7.1$ million). The differences between the estimated cost and the actually cost point out the difficulty of making estimates when dealing with changes in environmental regulations and changes in the competitive forces within the analytical services market place. Clearly, steps were implemented to reduce the chemical analysis costs. Given the current state of development of field-deployable chemical laboratories and the regulatory acceptance of field screening methods, it is difficult to envision a means by which the chemical analysis costs could have been reduced further. Additional reduction in the chemical analysis costs associated with environmental remediation requires the development of automated systems that meet the regulatory requirements and that can be deployed in the field. 
Table 6. Reconstruction of actual analysis cost

\begin{tabular}{lcccc}
\hline \multicolumn{1}{c}{ Project phase } & No. of samples & Per-sample cost & Laboratory type & Cost, (\$) \\
\hline $\begin{array}{l}\text { Remediation Phase Ib, } \\
\begin{array}{l}\text { Neutron Activation } \\
\text { Analysis }\end{array}\end{array}$ & 3,850 & $\$ 125$ & Off-site & $\$ 481,250$ \\
Wetlands study & 250 & 125 & Off-site & 31,250 \\
$\begin{array}{l}\text { ROD 400 ppm contour } \\
\text { bounding }\end{array}$ & 400 & 30 & On-site & 12,000 \\
$\begin{array}{l}\text { Confirmatory sampling } \\
\text { Confirmatory sampling }\end{array}$ & 1,244 & 30 & On-site & 37,320 \\
QA verification & 40 & 50 & Off-site & 2,000 \\
Laboratory QA check & 124 & 50 & Off-site & 6,200 \\
Waste acceptance & 1,800 & 50 & Off-site & 90,000 \\
Sample shipping & 6,064 & 3 & Not applicable & 18,192 \\
& & & Total cost & $\$ 678,212$ \\
\hline
\end{tabular}


Table 7. Cost estimate for all samples sent to an off-site laboratory

\begin{tabular}{lcccc}
\hline \multicolumn{1}{c}{ Project phase } & No. of samples & Per-sample cost & Laboratory type & Cost \\
\hline $\begin{array}{l}\text { Remediation Phase Ib, } \\
\begin{array}{l}\text { Neutron Activation } \\
\text { Analysis }\end{array}\end{array}$ & 3,850 & $\$ 125$ & Off-site & $\$ 481,250$ \\
Wetlands study & 250 & 125 & Off-site & 31,250 \\
$\begin{array}{l}\text { ROD 400 ppm contour } \\
\text { bounding }\end{array}$ & 400 & 50 & Off-site & 20,000 \\
$\begin{array}{l}\text { Confirmatory sampling } \\
\begin{array}{l}\text { Confirmatory sampling } \\
\text { QA verification }\end{array}\end{array}$ & 1,244 & 50 & Off-site & 62,200 \\
$\begin{array}{l}\text { Laboratory QA check } \\
\text { Waste acceptance }\end{array}$ & 124 & 50 & Off-site & 2,000 \\
Sample shipping & 1,800 & 50 & Off-site & 6,200 \\
& 7,708 & 50 & Off-site & 90,000 \\
& & 3 & Not applicable & 23,124 \\
\hline
\end{tabular}


Table 8. Cost estimate for maximum utilization of an on-site laboratory

\begin{tabular}{lcccc}
\hline \multicolumn{1}{c}{ Project Phase } & No. of Samples & Per-Sample Cost & Laboratory type & Cost \\
\hline $\begin{array}{l}\text { Remediation Phase Ib, } \\
\begin{array}{l}\text { Neutron Activation } \\
\text { Analysis }\end{array}\end{array}$ & 3,850 & $\$ 30$ & On-site & $\$ 115,500$ \\
Wetlands study & 250 & 30 & On-site & 7,500 \\
$\begin{array}{l}\text { ROD 400 ppm contour } \\
\text { bounding }\end{array}$ & 400 & 30 & On-site & 12,000 \\
$\begin{array}{l}\text { Confirmatory sampling } \\
\text { Confirmatory sampling }\end{array}$ & 1,244 & 30 & On-site & 37,320 \\
QA verification & 40 & 50 & Off-site & 2,000 \\
Laboratory QA Check & 124 & 50 & Off-site & 6,200 \\
Waste acceptance & 1800 & 30 & On-site & 54,000 \\
Sample Shipping & 164 & 3 & Not applicable & 492 \\
& & & Total Cost & $\$ 235,012$ \\
\hline
\end{tabular}

Table 9. Comparison between estimated and actual chemical analysis cost

\begin{tabular}{|c|c|c|}
\hline Cost Items From Table 6 & Actual & $\begin{array}{c}\text { Feasibility Study } \\
\text { estimate }\end{array}$ \\
\hline Confirmatory sampling & $\$ 37,320$ & $\$ 1,500,000$ \\
\hline Confirmatory QA & 2,000 & 660,000 \\
\hline Waste acceptance & 90,000 & $1,271,000$ \\
\hline Total & $\$ 129,320$ & $\$ 3,431,000$ \\
\hline
\end{tabular}

The value of an on-site laboratory capable of rapid data turnaround was discussed with John Lea. ${ }^{6} \mathrm{He}$ stated that 24 hour sample results turnaround time is "worth its weight in gold." The cost factors that this capability addresses are

- it eliminates sample shipping cost, 
- it substantially reduces costs associated with the treatment and discharge of groundwater infiltration into the excavated areas and the collected rainwater (The water becomes a hazardous waste that must be treated prior to disposal.), and

- it allows the remediation to proceed more quickly.

The impact of the on-site laboratory on the remediation work was reviewed by John Kubarewicz, Jacobs Engineering. ${ }^{15}$ The basis for his analysis was the confirmatory sampling and analysis plan for LEFPC. Without the near-real-time field analysis, either the remediation contractor would have had to cover the excavated areas to prevent rainwater from contacling the open areas, or the rainwater that collected in the excavated pits would have had to be pumped out and treated. Mr. Kubarewicz's analysis indicates the project schedule impact would have been 1 hour per day, or $12.5 \%$ longer project duration. Based on the $\$ 7.1$ million remediation cost, the additional project duration would have cost an additional $\$ 0.89$ million.

\section{CONCLUSIONS}

The LEFPC remediation project involved eliminating the potential human health hazard associated with the inadvertent ingestion of soils from the 100 year floodplain. Mercury was the only constituent of concern. Approximately $44,760 \mathrm{yd}^{3}$ of contaminated soil was excavated and disposed of in an approved landfill. The excavated areas were backfilled with clean soil to restore the original land contours, and the surface revegetated. The EPA-accepted, best demonstrated available technology for this cleanup involved thermal treatment of the soil to remove the mercury and use of the treated soil as backfill; this option was not selected for the cleanup because the full scale effectiveness and implementability of the process had not been proved.

An on-site laboratory was used during execution of the cleanup. The cost savings that the on-site laboratory provided fall into two categories:

- direct reduction of costs associated with chemical analysis and sample shipment totaling approximately $\$ 38,000$, which represents a 5.3\% savings relative to the estimated cost of using an off-site laboratory, and

- savings in the amount of $\$ 890,000$ (12.5\% of the $\$ 7.1 \mathrm{M}$ cleanup cost), associated with expediting execution of the cleanup work by providing rapid ( $<3$ hours) sample result turnaround time.

Given the current state of the art of field-deployable chemical laboratories and the regulatory acceptance of field screening methods, project management could not have achieved any additional cost savings.

The study indicates that the availability of automated chemical analysis systems that meet regulatory requirements and that can be deployed in the field (e.g., CAA-type technology) could have provided an additional savings of $\$ 443,000$ (the difference between the total cost shown in Tables 6 and 8 ). The study also indicates that the total savings, that automated field deployable analysis systems would have provided, compared with the conventional approach of sending all samples to an off-site laboratory, was about \$1.3 million (the sum of estimated savings provided by full field deployment of automated analysis systems,

\footnotetext{
${ }^{15}$ John Kubarewicz, Jacobs Engineering, personal communication to L. N. Klatt, April 29, 1997.
} 
$\$ 443,000$, and by expediting the cleanup, $\$ 890,000$ ), which represents a $18 \%$ savings of the $\$ 7.1 \mathrm{M}$ cleanup cost.

The manner in which the analytical chemistry services were procured by the LEFPC project suggests several important development considerations for the U.S. Department of Energy's Chemical Analysis Automation project. First, because the largest cost saving is associated with expediting the actual cleanup work, the automated chemical analysis systems must be site deployable and must provide rapid sample result analysis turnaround times commensurate with the specific cleanup work activities; generally, this would be less than 24 hours. Second, the performance of the automated analysis systems must meet the relevant state and federal regulatory requirements. Third, the automation system must be flexible and adaptable to facilitate the introduction of new chemical analysis methodology. Fourth, the automation technology must be robust and reliable. Finally, the automated systems must be implemented in a manner acceptable to the environmental remdiation business. The results from a recent technology demonstration show that CAA project has addressed each of the items. ${ }^{12}$ 


\section{INTERNAL DISTRIBUTION}

1. D. C. Haley

2. J. N. Herndon

3. M. A. Hunt

4-8. L. N. Klatt

9. T. E. Myrick

10. K. E. Plummer

11. B. B. Spencer

12. D. H. Thompson

13. J. R. Younkin

14. Central Research Library

15. ORNL Laboratory Records-RC

16-17. ORNL Laboratory Records-OSTI

\section{EXTERNAL DISTRIBUTION}

18. G. Boyd, U.S. Department of Energy

Office of Science and Technology EM-50

1000 Independence Avenue SW, Washington, DC 20585

19. D. M. Carden, DOE Oak Ridge Operations Office P.O. Box 2001, Oak Ridge, TN 37831

20. M. Clark, Idaho National Engineering \& Environmental Laboratory, P.O. Box 1625, MS 2220,Idaho Falls, ID 83415-2220

21. D. E. Dale, Los Alamos National Laboratory P.O. Box 1663, MS K484, Los Alamos, NM 87545

22. J. DeGregory, U.S. Department of Energy 19901 Germantown Road, Germantown, MD 20874-1290

23. J. Lea, Jacobs Engineering, 125 Broadway Ave., Oak Ridge, TN 37830

24. R. Hirsch, APTI, $125024^{\text {th }}$ Street, NW, Suite 850, Washington, DC 20037

25-34. K. Humphrey, Los Alamos National Laboratory P.O. Box 1663, MS J580, Los Alamos, NM 87545

35. R. M. Hollen, Los Alamos National Laboratory P.O. Box 1663, MS J580, Los Alamos, NM 87545

36. M. Monagle, Advanced Industrial Chemistry Corp. 9220 Jill Patricia NW, Albuquerque, NM 87114

37. J. Moore, DOE Oak Ridge Operations Office P.O. Box 2001, Oak Ridge, TN 37831

38. D. Green, DOE Oak Ridge Operations Office P.O. Box 2001, Oak Ridge, TN 37831

39. Ivan C. Oelrich 1801 N. Beauregard Street, Alexandria, VA 22311

40. A. Perkins, DOE Oak Ridge Operations Office P.O. Box 2001, Oak Rige, TN 37831 
41. R. Rubin, Institute for Defense Analysis,

1801 N. Beauregard Street, Alexandria, VA 22311

42. C. Rzeszutko, Los Alamos National Laboratory

P.O. Box 1663, MS J580, Los Alamo:s, NM 87545

43. D. Wadsworth, Idaho National Engineering \& Environmental Laboratory

P.O. Box 1625, MS 2220, Idaho Falls, ID 83415-2220

44. J. S. Walker, DOE-HQ, U.S. Department of Energy 19901 Germantown Road, Germantown, MD 20874

45. L. Yarbrough, DOE Albuquerque Operations Office

P.O. Box 5400, Albuquerque, NM 87185-5400 